Paweł Kot*

DOI: $10.2478 / v 10241-012-0033-3$

Bohdan Rożnowski

\title{
Self-efficacy beliefs of youth entering the labour market
}

\section{ABSTRACT}

This article presents the psychological meaning of school-to-work transition. Transition to taking up new social roles entails numerous difficulties, and that is why young people see it as a crisis point. According to researchers one of the predictors of effective transition to the labour market is self-efficacy.

This article presents the two obtaining approaches to the psychology of self-efficacy beliefs. Both specific and generalized self-efficacy belief are good predictors of human behaviour, which has been repeatedly confirmed in the studies (main overview in this article).

The authors of this compilation have integrated the two dominating approaches into one theoretical model, taking account of the three levels of generality proposed by Rosch. By doing that, a theoretical model has been created which allows for organising self-efficacy beliefs relating to life roles into a three-level hierarchical structure.

* Correspondence regarding the paper should be sent to: Paweł Kot, Department of Organisational and Management Psychology, The John Paul II Catholic University of Lublin, Al. Racławickie 14, 20-950 Lublin, e-mail: pawelkot@kul.lublin.pl 


\section{INTODUCTION}

Work is the most important type of human activity - from the moment we become mature, we try to obtain the resources which provide for our existence and living standards. Entering the labour market is for a young person one of the stages in career development (Rożnowski, 2009). It is a crucial moment in their professional development. The proof of gravity of such a transition is the fact that the youth unemployment rate is twice as high as for other age groups (Central Statistical Office, 2012). Also, empirical studies of near high school and university leavers show that the moment of leaving the school and entering the labour market arouses strong emotions among young people (Rożnowski et al., 2006). Entering the labour market is a crisis point for young people, it entails taking up numerous new activities (Bańka, 2005b). Such a transition is equated with taking up new development-related tasks and described at length in the literature (Marcia, 1966; Inhelder, Piaget, 1969; Erikson, Erikson, 1987).

School-to-work transition should be equated with the entry into the adult life (Savickas, 1999; Tchibozo, 2002; Hartel et al., 2005). Employment and regular income earned allow for becoming self-reliant also in other spheres of social life (as a spouse, parent, consumer, leisurite). That is why this moment can be treated as a transition. In psychology, the term is used to define moving from one existential situation to another. In psychological literature, especially from the last years, this term is used widely (Fouad, Byner, 2008; Hopwood, et al., 2011; Keizer, Dykstra, Poortman, 2010; Poulin, Hackhausen, 2007; Tamir, John, Srivastava, Gross, 2007). Transition may result both from entering into new social roles and changing our current situation in life. The term is used to define all such events which modify our major life goals or the ways of their achievement (Poulin, Hackhausen, 2007). Poulin, Hackhausen (2007) differentiate between minor and major 
life transitions. Apart from the school-to-work transition (Heckhausen, Tomasik, 2002), major life transitions include child birth, emigration or losing someone close to you. A common feature of all these events is the scale of change in the life situation and the necessity to generate a new way of self-fulfilment.

\section{SCHOOL-TO-WORK TRANSITION AS A STEP INTO ADULTHOOD}

Transition into adulthood, which is inseparably linked with taking up the role of an adult and finding sources of income, most frequently means taking up gainful employment (Bańka, 2010). Transition into adulthood is not only taking up your first employment, but also keeping it for a while in order to meet the obligations resulting from taking up new social roles (Bańka, 2005b). A key element in stepping into adulthood is transition from the receptive, subordinate, dependent role which is typical of the education system - the role of a child and a pupil, to the world of work, which is in the general opinion connected with independence, responsibility, giving and generating - the role of an adult, worker. Arnett's research (2000) shows that not everyone reaches the development level called adulthood at the age considered so far as appropriate (approx. 24). The research proved that a significant percentage, i.e. $25 \%$ of the respondents being 35 declared that they did not feel as adults yet (mature).

Transition to the labour market is an experience extremely important for the subsequent development of our career over the life span. Successful transition translates into our self-efficacy, ability to get by, it accelerates learning of a new role at work, influences our satisfaction from the colleagues and standards at work - it consolidates our choice of the profession (Rożnowski, 2009). On the other hand, unsuccessful transition results in graduate unemployment (Rożnowski, 2007). 
A critical period when we are best adapted to transition is early adulthood. This is when we are substantially flexible in terms of cognition - we show strong capabilities of adaptation to a new work situation, and at the same time we have become mature enough to establish a career that we can plan and develop it on a long-term basis (Bańka, 2005b). We take first steps in our professional life (Czerska, 2008), establish more mature interpersonal and intimate relationships and take up new social roles (White, Jackson, 2004/2005). Students are a group which enters the labour market as the last one, owing to which their cognitive system is best developed (Rożnowski, 2009). The research shows that during early adulthood, apart from the need of relationships with people, activity and work occupy the highest position in the hierarchy of needs (Czerwińska-Jasiewicz, 2005). However, these are the areas where their feeling of fulfilment is the lowest. In turn, during middle and late adulthood the key needs include the need of safety and relationships with people (Brzezińska, Stolarska, Zielińska, 2002). Surveys confirm the above, showing that gainful employment is very important for young people (Rożnowski et al., 2007). In addition, when planning their future after completing education, first of all young people want to find employment and then devote to other roles (Rożnowski, 2009). Preparing youth to transition means to prepare a person to a creative transition to the labour market for effective development and meeting the goals important for an entity as a person (John Paul II, 1986).

Development-related tasks related to transition to adulthood, such as fulfilling the professional role, choosing a partner in life or starting a family, gradually lose their meaning in favour of individual preferences, which are more adequate to life situation (Czerska, 2008). Changes observed in the lifestyle of young people are to a large extent the result of social and economic transformations, with the roots deep inside the human personality (Bee, 2000). Thus, university graduates find themselves in a difficult moment in life. On the one hand, sudden developmental 
changes experienced during adolescence, thanks to which they became mature from the biological perspective, are over (Bee, 2000). In addition, acceleration which can be observed with every generation gradually lowers the age of biological adulthood (Piotrowski, 2010). On the other hand, unstable situation on the labour market, low income and the constant need to improve professional qualifications result in prolonging the moment of taking up the obligations of adulthood (Czerska, 2008). The situation results in extending the process of entering into adulthood - young people oscillate between the carelessness of adolescence and the obligations connected with adulthood (Czerska, 2008). Finding themselves forced to leave school to which they have managed to adapt well throughout several years, young people try to extend transition to the labour market by prolonging their complete entry into adulthood (Rożnowski, 2009). Refraining from complete involvement in pursuing new challenges, they limit the possibility of achieving full intellectual, emotional, social and personal maturity (Bee, 2000).

What is becoming increasingly popular among young people, especially university graduates, is the so-called "gap year" being a voluntary period when students do not study or work, which separates studying from becoming a full-time employee and consequently delays the beginning of a professional career (Mrozińska , 2011). However, longer studying only seemingly eliminates the problem of unemployment - even the longest studies end one day and you enter the labour market. Such an attitude leads to even worse frustration of young people who deceptively believed that university education is a key to success (Czerska, 2008).

DONALD SUPER'S LIFE-CAREER RAINBOW

Among numerous concepts in career counselling (Parsons, 1909; Holland, 1999; Roe, 1956), professional development was 
described most widely by Super (1990). Super (1994) understands career maturity as a measure of self-awareness, ability to plan your personal development and knowledge of occupations. Entering the labour market means taking up the worker role, and at the same time young people take up other life roles. Super argued that the self-image in professional development is more important than interests. Subjective conceptions of ourselves in a specific role or situation are the source of assessing our own ability to fulfil the roles taken up (Guichard, Huteau, 2005).

The life-career rainbow model by Super (1992) presents the structure of roles of a human being in individual phases and cycles of their personal and professional life. The concept assumes that throughout the lifespan an individual takes up six main social roles (Super, Savickas, Super, 1996). According to Super (Super, Larry, 1992), the basic social roles and corresponding main personal and professional activities are: a child (playing professional roles), a student (acquiring knowledge), a worker (earning, professional development), a homemaker (creating a home, organisation of family life), a leisurite (active and passive recreation), a citizen (public, civic and political duties).

Social roles are not permanently assigned to a specific age. Even several roles may appear at the same time, which can be of different importance for an individual (Super, Savickas, Super, 1996). If we take students, apart from the obvious role of a student, each of them is also a homemaker, a citizen, some are workers already. Roles which are being fulfilled are interrelated. Each of them may supplement, expand or disturb the progress of a life career (Super, 1994). Not all roles have the same importance at the same time for a given individual, who may focus more on the homemaker role than worker role, or the other way round. It all depends on what is more important to us at a given stage in life and what will give us more satisfaction (Januszkiewicz, 2009). Roles are not assigned once and for all - they may intertwine in 
a life cycle, new ones may appear, and their importance may change (Guichard, Huteau, 2005).

This model was used in other research (Brzezińska et al., 2002) and sometimes modified by incorporating additional roles or their reduction (Savickas, 1994; Cossette, Allison, 2007). Functioning in the social roles defined by Super according to the concept by Hazel Markus (1977) will generate various working self, e.g. occupational self (Holland 1999; Super 1994). Each individual has at least several self-concepts (possible self). The fact which concept is activated and becomes the current working self depends on the cognitive interpretation of a situation in which a given person finds themselves (Markus, 1986).

Individual working self may have various content within different selves (Markus, Nurius; 1986) - a person may be convinced of their self-efficacy as a worker, and at the same time not see themselves as an efficient parent or a homemaker. It is the result of various personal experiences in various roles (e.g. being a good parent may never be considered in relation to being a sportsman). We can make distinctions within a given substructure of the self by generating a mix of positively and negatively valenced elements (Markus, Cross, 1990). Coherent evaluation in a given substructure of the Self may blur specific functions as regards information, but this feature gives basis for explicit behaviours (Cervone, Pervin, 2009). Markus (Markus, Nurius; 1986) proposed the concept of the self-schema to describe the area of the Self with regard to which an individual shows precise views and extensive knowledge - self-schemas are generated in the areas important for us because they make us different from the others, define our value and refer to the activities we undertake (Markus, 1977). It is easy to change the evaluation of the information poorly related to the self, whereas it is much more difficult to change the central aspect of the self (Markus, Cross; 1990). As a consequence of the processes of organising their system by the self, its various spheres may be coherent to a various extent (e.g. the self as a great par- 
ent, but a lousy worker), which does not exclude the possibility of still being the same coherent person (Oleś, 2009).

Bandura (1986) stresses that one of the detailed aspects of the self, that is self efficacy, plays the key role in an individual's functioning. Bandura (2000) includes self-efficacy among core beliefs based on which all other beliefs comprising the individual's full functioning are shaped. Self-efficacy leads to generation of expectations as to the result of an action taken (Bandura, 2001). The key role of such a conviction is also accepted by other researchers (Schwarzer, Jerusalem, 1992; Zimmerman, Bonner, Kovach, 2005; Łaguna, 2010; Caprara et al., 2004; Betz, 2004; Lent et al., 2005; Nasta, 2007). According to Bandura (2001), the measurement of self-efficacy should be adapted to the area of psychological functioning subject to analysis. He calls for the development of a method for measuring self-efficacy in specific activity areas, e.g. work, studying. In Markus' concept (1985), the social roles identified by Super could be a source of forming possible selves and working selves activating in a given situation. The roles defined may also designate areas of human activity within the limits of which people may acquire specific self-efficacy beliefs. In cognitive concepts of personality, the key element in individual's functioning in a given role is their self-efficacy, e.g. as a worker (Lent, Brown, Hackett, 2000) or a student (Zimmerman, Bonner, Kovach, 2005).

\section{RESEARCH ON SELF-EFFICACY}

Self-efficacy is the individual's belief in their ability to succeed in new, ambiguous, unforeseeable or stressful situations (Bandura, 2000). The term refers to a person's conviction of being capable of succeeding in specific situations or performing a specific task (Bandura, 1997). It is the individual's subjective judgement about 
their abilities, without the actual and reliable evaluation of the actual competencies they possess (Eaguna, 2006).

Self-efficacy determines the level of self-motivation, emotional state as well as the expenditure of effort and persistence in the face of obstacles (Bandura, 1997). According to the assumption adopted by Bandura (2001), self-efficacy is a better predictor of the individual's achievements than previous achievements, knowledge or abilities. Being one of self-regulating processes, self-efficacy has impact on thinking processes, motivation level and emotional states of a person, and by that it has impact on their behaviour (Bańka, 2005a). Apart from the direct impact on behaviour, self-efficacy also indirectly influences our actions, i.e. it participates in the process of selecting goals (Lent, Brown, Hackett, 2000). It takes place by creating the level of aspiration as to the goal and level of effort, and also by the tendency to persist despite obstacles and barriers (Łuszczyńska, 2004).

The measurement of our self-efficacy may comprise three dimensions: magnitude, strength and generality (Bandura, 2007).

A person with a strong self-efficacy belief positively evaluates their own abilities. They have a sense of control over their behaviour and surroundings (Łuszczyńska, 2004). They believe in their ability to tackle even difficult tasks (Bańka, 2005a). They focus on their capabilities, and perceive obstacles as surmountable. This fosters quicker processing of information, better task performance and adequate formulation of goals (Bandura, 2001). Perceiving themselves as efficient in a specific area, an individual is motivated to take up very difficult activities (Eaguna, 2010). It allows to accurately measure the effort and time needed to perform a task, which leads to greater involvement and consequently effective operation, even despite an objectively difficult task (Bandura, 2001). By that, a person successfully completes their activities and as a result strengthens their self-efficacy (Bandura, 1997). A person with a strong sense of self-efficacy is also 
open to the necessity to change their behaviour, and the changes made last longer (Łuszczyńska, 2004).

In turn, persons with a low sense of self-efficacy have lower ambitions and show a low level of involvement in the activities which would help them fulfil the desired goal (Feltz, Lirgg, 2001). Facing difficulties, they give up faster (Bańka, 2005). The observed inability to manage difficult situations leads to fear and higher anxiety, which blocks the ability to accurately assess the situation and use more efficient procedures (Bandura, 2001). Such a person is focused on themselves and a possible failure instead of focusing on the task and the ways of its effective performance (Bassi et al., 2007). Failure experience creates a pessimistic approach to life and further lowering of the opinion of one's own ability to manage things effectively (Oleś, Drat-Ruszczak, 2008). As a consequence, even if there is success it is limited compared to the accompanying circumstances (Łaguna, 2006). Perceiving one's inefficiency in dangerous situations may even lead to intensified anxiety reactions, and the related lack of success in fulfilling defined goals may be the cause of depression (Pervin, John, 2001).

Beliefs of self-efficacy shape during development, and experiences gained in the early life stages influence human functioning in subsequent stages. Bandura (1977) identifies four main factors shaping strong self-efficacy: accomplishments, vicarious experience, verbal persuasion and emotional cues.

In numerous studies, self-efficacy turned out to be a very good predictor allowing for justification of various human behaviours, e.g. health behaviours (Schwarzer, Jerusalem, 1995; Juczyński, 2001; Kościelak, 2010); entrepreneurship (Łaguna, 2005, 2006); attending courses (Łaguna, 2010), occupational effectiveness (Chen, Casper, Cortina, 2001); participation in political life (Caprara, Vecchione, Schwartz, 2009); pro-social behaviours (Caprara at al, 2010); sports activity (Morris, Summers, 2000; Feltz, Lirgg, 2001). What seems to be especially promising is the contribution of self-efficacy to the choice of our own career path (Lent, 
Brown, Hackett, 2000) and educational achievements (Caprara at al., 2004; Zimmerman, Bonner, Kovach, 2005; Britner, Pajares, 2006, Caprara at al., 2011). A broader survey of research confirming the impact of our self-efficacy in various spheres of human functioning can be found in meta-analyses of the research done (Multon, Brown, Lent, 1991; Stajkovic, Luthans, 1998).

\section{GENERALISED VS. SPECIFIC SELF-EFFICACY}

Self-efficacy is treated as an important behaviour predictor (Kościelak, 2010). Researchers lack such agreement as to the level of generality (Schwarzer, 1997) or specificity (as Bandura would wish, 2007) of self-efficacy.

According to Bandura (2001), self-efficacy refers to the perceived ability to perform a specific task or achieve a given level in performing such a task (Bandura, 2007). In his opinion, if we want to predict somebody's behaviour, we cannot be influenced by the generalised sense of self-efficacy, but the self-efficacy typical of a given, specific behaviour (Bandura, 2001). The global selfimage does not explain the complexity of beliefs in self-efficacy, which differ depending on the type of activity, level of activity and various environmental conditions (Bandura, 1986). Only by adopting the most specific evaluation of self-efficacy limited to a narrow area can we accurately predict an individual's behaviour (Łuszczyńska, 2004). Thus, some authors limit defining their self-efficacy to very specific behaviours (e.g. handling a heart disease, Kościelak, 2010). This obliges the researchers wishing to study beliefs in self-efficacy in various areas to construct new tools which encompass the specificity of activity (Łaguna, 2005).

Some researchers question the sense of such a narrow comprehension of self-efficacy and call for the measurement of generalised sense of self-efficacy (e.g. Schwarzer, Jerusalem, Juczyński). A generalised sense of self-efficacy is the individual's 
generalised, relatively permanent belief in their sufficient ability to perform successfully in a variety of situations (Schwarzer, Jerusalem, 1992). The level of generalised self-efficacy is responsible for initiating and maintaining a behaviour, is more important than the expectations as to the result of a given behaviour or the effect (specific self-efficacy) (Scholz et al., 2002). It allows for the justification of a broader context of human behaviours (Schwarzer, Jerusalem, 1995). Analyses of various levels of generality of self-efficacy beliefs show that in the case of goal fulfilment the generalised sense of self-efficacy may be more important (Scholz at al., 2002). Similarly, Markman, Baron, Balkin (2005) point to the generalised self-efficacy as a better predictor of success, especially if the activity is taking place in complicated circumstances and the task is multi-dimensional (e.g. starting a business). A similar multi-dimensional and complex situation which requires meeting long-term goals is the choice and pursuit of a career, and that is why the usefulness of such a construct was tested in a survey regarding young people in the transition period (Rożnowski, 2007).

Indeed, applying the most specific self-efficacy beliefs is a guarantee of high accuracy in predicting human behaviours, however studying an unlimited number of various self-efficacy beliefs is hardly practical (Bosse et al., 2002). In turn, the generalised sense of self-efficacy covers a wide scope of human behaviour, however shows low accuracy in predicting human behaviour. It does not take account of the fact that people react differently to various situations - in some they feel effective and uncertain and lost in others (Pervin, 2005).

Self-efficacy specific to a task or a situation and the generalised sense of efficacy are considered to be two different constructs in terms of the concept and psychometrics (Skaalvik, Skaalvik, 2004). These differences are confirmed in statistical analyses and numerous surveys (Eaguna, 2010). Eden (1988) and Judge (1997) suggest that specific self-efficacy is a motivational state, more prone to various types of factors, and the generalised sense is a person- 
ality feature (more permanent), i.e. its nature is similar to fear, which functions in psychology as a state or feature of a person (Spielberger, 1996).

The usefulness of both the generalised and specific self-efficacy confirmed in numerous studies in predicting and explaining human behaviour encourages researchers to make attempts to combine the advantages of the two approaches (Euszczyńska, 2004), the more so as both the self-efficacy belief and the generalised sense of self-efficacy have in numerous studies turned out to be a good predictor of human behaviours (Kościelak, 2010).

\section{HIERARCHICAL STRUCTURE OF SELF-EFFICACY BELIEFS}

An interesting solution to this problem seems to be the adoption of a hierarchical structure of self-efficacy beliefs - from the generalised belief irrespective of the situation, through specific belief in narrower areas to self-efficacy in handling very specific tasks (Skaalvik, Skaalvik, 2004). Based on various experiences where a person turned out to be efficient, not only a conviction of efficacy in a specific situation is developed, but also a more generalised conviction (Cervone, 1997). Caprara (Caprara et al., 2011) thinks that self-efficacy can become generalised. Thanks to the ability of self-awareness, self-efficacy developed in one area may be generalised and show in various situations. We may distinguish specific self-efficacy beliefs, e.g. self-efficacy in individual school subjects (e.g. maths, English) and a more general conviction (comprising e.g. ability to plan and organise studying, having our own learning strategies) finally make up our self-evaluation as a student (Caprara et al., 2010).

That being so, when studying self-efficacy comprising a broader area of activity (e.g. one of the life roles) we may use numerous specific convictions referring to specific tasks and situations within this area (Chen, Greene, Crick, 1998). This allows for both 
measuring self-efficacy in the narrowly defined sense and also in the more general one. According to Bosse (Bosse et al., 2002), if the purpose of the research is narrower we can use specific selfefficacy, and if it is general we remain at the generalised level. However, the solution does not seem to be totally a good one. What raises doubts is the reason why we can focus on general convictions on some occasions, and on specific convictions on others (Kościelak, 2010).

A similar dilemma appeared for the notion of the self which takes numerous forms, just like self-efficacy (Pervin, 2003). Complex organisation of the system of the self implies a question about the rules which define the functioning and internal organisation of a system (Oleś, 2009). Despite the research on the self initiated by William James more than 100 years ago, there is no agreement among researchers about the organisation of the self systems. Baumeister (1990) claims that the structure of the self is made up of various modules which may function independently, and defines the self as a set of loosely linked beliefs about ourselves.

In turn, Cantor, Kihlstrom $(1987,1989)$ claim that the self-concept is a notion and just like any other notion it has a hierarchical structure (reference to Rosch's theory). Each person has numerous self-concepts, e.g. occupational, recreational, school, family self and many others (Pervin, 2003). In addition, within each self type we can find other subtypes, e.g. in the family self we can find the self of a child of its parents, the Self of a parent for their children, the self of a brother or sister for possible siblings (Cervone, Pervin, 2009). The complexity of the self system and the modular nature of its organisation and functioning are accurately reflected in the concept of the working self and possible self (Markus, 1985). People may organise the hierarchical structure of their Self depending on individual criteria, thus individuals have unique selves (Cervone, Pervin, 2009). Cantor, Kihlstrom (1989) claim that the self hierarchy depends on the situational context which means that the construction and structure of the self may 
be different in various situations. What proves the hierarchical structure of the self according to Kihlstrom, Klein (1997) is the fact that the self is structured on the knowledge of general features based on the memory of specific behaviours.

Multiplicity of differentiated selves on the one hand makes it possible to have and use various action plans depending on the situation, which is very important for adaptation (Pervin, 2002). On the other hand, it raises doubts about how a person recognises themselves in frequently substantially different images and associated roles or behaviours, e.g. a person can be quiet at work, but violent at home (Oleś, 2009). Cantor, Kihlstrom (1989) point to three elements thanks to which a person and its environment may recognise one and the same person despite multiple selves: all selves have some shared, similar elements, autobiographical memory and the sense of continuity of personal experience plus we can always return to our basic self. In this way a person is able to handle differences between their self-knowledge, self-esteem and behaviour (Pervin, 2003).

Owing to the fact that self-efficacy is one of the aspects of the Self, it seems justified to refer also in this case to Rosch's prototype theory (Kihlstrom i Klein, 1997). With the use of the three levels of generality as proposed by Rosch (1978), we can suggest a theoretical model which allows for organising self-efficacy beliefs into a three-level hierarchical structure.

The subordinate level comprises extremely detailed notions with a big number of characteristics, which makes it less easy to identify designata of notions because many different items are characterised by a very similar level of features (Rosch, 1983). In the case of efficacy belief this level is represented by a conviction of handling tasks characteristic of everyday functioning in a given role, e.g.: preparing to an exam, learning new material, writing an exam.

The basic level is the most frequently used level of generality of representation, which has a greater number of features charac- 
terising conceptual representations compared to the general level (Rosch, 1983). With reference to self-efficacy it is limited to the conviction of efficacy in performing social roles, such as a student, worker, homemaker, leisurite, citizen (Super, 1994).

The superordinate level - notions at this level are reflected by a small number of features, by which it has wide inclusiveness, it comprises a number of items (Rosch, 1978). It is the most generalised structure, it is represented by generalised self-efficacy as understood by Schwartzer, Jerusalem (1992), it has a nature of a general conviction of one's competencies and does not refer to any specific situation.

\section{CONCLUSSIONS}

Transition from school to work is a complex phenomenon and increasingly prolonged in time (Bańka, 2010). Facing the global economic crisis and limited opportunities to effectively enter the labour market, more and more young people are trying to prolong for as long as possible their stay in the educational environment which is safe, unlike the labour market (Rożnowski, 2007). In American conditions, the Social Cognitive Career Theory (SCCT) by Lent, Brown, Hacket (2000) based on the self-efficacy belief is doing well in explaining conditions for a career and success on the labour market. The research done so far in Poland has not confirmed strong relations between self-efficacy beliefs and effective transition (Rożnowski, 2007). It seems that this is due to considering only the generalised sense of self-efficacy which may not exhaust the specificity of this phenomenon.

The three-level model proposed at the end of this article, which integrates both specific and generalised self-efficacy, is a theoretical attempt to explain the issue. The theoretical model proposed, which takes account of the hierarchical structure of self-efficacy beliefs requires empirical verification. 
Developing a model and its further empirical verification will be a reply to the needs and expectations of youth preparing to transition to the labour market. The research done so far is insufficient to get the full picture of this extremely dynamic phenomenon, by which we lack a systemic presentation of transition from school to work. Consequently, independent planning of the transition path by young people is not always effective (Bańka, 2011).

\section{REFERENCES}

Arnett, J.J. (2000). Emerging Adulthood: A Theory of Development From the Late Teens Through the Twenties, American Psychologist, 55, (5), 469-480.

Bandura, A. (1977). Social Learning Theory. Englewood Cliffs, NJ: Prentice Hall. Bandura, A. (1986). Social Foundations of Thought and Action: A Social Cognitive Theory. Englewood Cliffs, NJ: Prentice-Hall.

Bandura, A. (1997). Self-efficacy: the exercise of control. New York: Freeman.

Bandura, A. (2000). Cultivate self-efficacy for personal and organizational effectiveness. In: E. A. Locke (Eds.), Handbook of principles of organization behavior (pp. 120-136). Oxford: Blackwell.

Bandura, A. (2001). Social cognitive theory: an agentic perspective. Annual Review of Psychology, 52, 1-26.

Bańka, A. (2005a). Poczucie samoskuteczności. Konstrukcja i struktura czynnikowa Skali Poczucia Samoskuteczności w Karierze Międzynarodowej. Poznań: Print-B. Bańka, A. (2005b). Zawodoznawstwo, doradztwo zawodowe, pośrednictwo pracy. Psychologiczne metody i strategie pomocy bezrobotnym. Poznań: PrintB.

Bańka, A. (2010). Psychologia doradztwa kariery. Poznań: SPiA.

Bańka, A. (2011). Psychologia pracy i organizacji w dobie ponowoczesności. In: B. Rożnowski, M. Łaguna. (Eds.), Człowiek w pracy i organizacji (pp. 10-40). Lublin: Wyd. KUL.

Bassi, M., Steca, P.,Fave, A., Caprara, G. V. (2007). Academic Self-Efficacy Beliefs and Quality of Experience in Learning, Journal of Youth Adolescence, 36, 301-312.

Baumeister, R. F. (1990). Suicide as escape from self. Psychological Review, 97, 90-113. 
Bee, H. (2000). Child and Adolescent Development. Boston: Pearson Custom Publishing.

Betz, N. E. (2004). Contributions of self-efficacy theory to career counseling: a personal perspective. Career Development Quarterly, 52, 340-353.

Bosse, M. J., Kellam, J. F., Burgess, A. R., Webb, L. X., Swiontkowski, G., Rohde, C.A. (2002). Factors influencing the decision to amputate or reconstruct after high-energy lower extremity trauma. Patient Education and Counseling, 54, (1), 95-99.

Britner, S. L., Pajares, F. (2006). Sources of science self-efficacy beliefs of middle school students. Journal of Research in Science Teaching, 43, 485-499.

Brzezińska, A., Stolarska, M., Zielińska, J. (2002). Poczucie jakości życia w okresie dorosłości. In: K. Appelt, J. Wojciechowska. (Eds.), Zadania i role społeczne w okresie dorostości (pp. 103-126). Poznań: Wydawnictwo Fundacji Humaniora.

Cantor, N., Kihlstrom, J. F. (1987). Personality and social intelligence. Englewood Cliffs, NJ: Prentice-Hall.

Cantor, N., Kihlstrom, J. F. (1989). Social intelgence and cognitive assessments of personality. Advances in Social Cognition, 2, 1-59.

Caprara, G. V., Alessandri, G., Di Giunta, L., Panerai, L., Eisenberg, N. (2010). The contribution of agreeableness and self-efficacy beliefs to prosociality. European Journal of Personality, 24, 36-55.

Caprara, G. V., Barbaranelli, C., Pastorelli, C., Cervone, D. (2004). The contributionof self-efficacy beliefs to psychosocial outcomes in adolescence: Predicting beyond global dispositional tendencies. Personality and Individual Differences, 37, 751-763.

Caprara, G. V., Vecchione, M., Alessandri, G., Gerbino, M., Barbaranelli, C. (2011). The contribution of personality traits and self-efficacy beliefs to academic achievement: A longitudinal study. The British Psychological Society, 81, 78-96.

Caprara, G. V., Vecchione, M., Schwartz, S. H. (2009). The mediational role of values in linking personality traits to political preference. Asian Journal of Social Psychology,12, 82-94.

Cervone, D. (1997). Social-cognitive mechanisms and personality coherence: Self-knowledge, situational beliefs, and cross-situational coherence in perceived self-efficacy. A journal of the American Psychological Society, 8, 43 - 50.

Cervone, D., Pervin, L.A. (2009). Personality theory and research. NY: Wiley and Sons

Chen, G., Casper, W. J., Cortina, J. M. (2001). The role of self-efficacy and task complexity in the relationships among cognitive ability, conscientiousness, and work-related performance: A meta-analytic examination. Human Performance, 14, 209-230. 
Chen, G., Gully, S. M., Eden, D. (2001). Validation of a new general self-efficacy scale. Organizational Research Methods, 4, (1), 62-68.

Chen, C., R. Green, P., Crick, A. (1998). The self-efficacy expectations and occupational

preferences of females and males. Journal of Business Venturing, 13(4), 295-316.

Cossette, I., Allison, C. J., (2007) Three Theories of Career Development and Choice. Edmonds Community College.

Czerwińska-Jasiewicz, M. (2005). Rozwój psychiczny młodzieży a jej koncepcje dotyczace własnego życia. Warszawa: Wydawnictwo Instytutu Psychologii PAN.

Czeska, E. (2008). Polityka społeczna krajów Unii Europejskiej wobec kwestii wkraczania młodych ludzi w dorosłość. Studia Gda skie, V, 109-122.

Erikson, E. H., Erikson, J. M. (1987). The Life Cycle Completed. W.W. Norton, Co.

Feltz, D. L., Lirgg, C. D. (2001) Self-efficacy Beliefs of Athletes, Teams, and Coaches. In R. N. Singer, H. A. Hausenblas, C. Janelle (Eds.), Handbook of Sport Psychology (pp. 340-361). New York: John Wiley, Sons.

Fouad, N. A., Bynner, J., 2008. Work Transitions, American Psychologist, 63, 4, 241-251.

Guichard, J., Huteau, M. (2005). Psychologia orientacji i poradnictwa zawodowego. Kraków: Impuls.

Hartel, P., Noworol, Cz., Bańka, A., Kremser, R. (2005). Transition to the world of work. Kraków: Jagielonian Uniwersity.

Heckhausen, J., Tomasik, M. J. (2002). Get an apprenticeship before school is out: How German adolescents adjust vocational aspirations when getting close to a developmental deadline. Journal of Vocational Behavior, 60, 199-219.

Herr, E. L., (1997). Super's life-span, life-space approach and its outlook for refinement. Career Development Quarterly, 45, 3, 238-246.

Holland, J. L. (1999). Why interest inventories are also personality inventories. In M. L. Savickas, A. R. Spokane (Eds.), Vocational interests: Meaning, measurement, and counseling use (pp. 87-101). Palo Alto, CA: Davies-Black.

Hopwood, C.J., Donnellan, M.B., Blonigen, D.F., Krueger, R.F., McGue, M., Iacono, W.G., Burt, S.A. (2011). Genetic and Environmental Influences on Personality Trait Stability and Growth During the Transition to Adulthood: A Three-Wave Longitudinal Study, Journal of Personality and Social Psychology, 100, 3, 545-556.

Jan Paweł II (1986). Laborem exercens. Tekst $i$ komentarze. Lublin: RW KUL. Januszkiewicz, K. (2009). Rozwój zawodowy. Szanse i zagrożenia. Łódź: WUŁ. Judge, T. A., Erez, A., Bono, J. A. (1998). The power of being positive: The relation 
between positive self-concept and job performance. Human Performance, 11, 167-187.

Juczyński, Z. (2001). Narzędzia pomiaru w promocji i psychologii zdrowia. Warszawa: Pracownia Testów Psychologicznych PTP.

Keizer, R., Dykstra, P. A. Poortman, A-R., (2010). The Transition to Parenthood and Well-Being: The Impact of Partner Status and Work Hour Transitions. Journal of Family Psychology, 24, 4, 429-438.

Kościelak, R. (2010). Poczucie umiejscowienia kontroli i przekonania o własnej skuteczności w zdrowiu i chorobie. Kraków: Impuls.

Łaguna, M. (2005). Spostrzeganie własnej skuteczności i koncepcja Ja u osób bezrobotnych. Psychologia Rozwojowa, 10, 69-78.

Łaguna, M. (2006). Skala Skutecznej Przedsiębiorczości. Roczniki Psychologiczne, $9,99-123$.

Łaguna, M. (2010). Przekonania na własny temat i aktywność celowa. Gdańsk: GWP. Lent, R. W., Brown, S. D., Hackett, G. (2000). Contekstual supports and barriers to Career choice: A social Cognitive analysis. Journal of Counseling Psychology, 47, 1, 36-49.

Lent, R. W., Singley, D., Sheu, B-H., Gainor, K. A., Brenner, B. R., (2005). Social Cognitive Predictors of Domain and Life Satisfaction: Exploring the Theoretical Precursors of Subjective Well-Being. Journal of Counseling Psychology, $52,429-442$.

Łuszczyńska, A. (2004). Zmiana zachowań zdrowotnych. Gdańsk: GWP.

Marcia, J. E., (1966). Development and validation of ego identity status. Journal of Personality and Social Psychology, 3, 551-558.

Markus, H. R. (1977). Self-schemata and processing information about the self. Journal of Personality and Social Psychology, 35, 63 - 78.

Markus, H., Cross, S. (1990). The interpersonal self. In: L. A. Pervin (Eds.) Handbook of personality: Theory and research (pp. 576-608). NY: Guilford.

Markus, H., Nurius, P. (1986). Possible selves. American Psychologist, 41, 954-969.

Morris, T., Summers, J. (1998). Psychologia sportu. Strategie i techniki. Warszawa: COS.

Mrozińska, J. (2011). Jak młodzi Polacy przesypiaja kariery? Pobrano: 21 Październik 2011, z: http://www.uniface.pl/Jak-Polacy-przesypiaja-wlasne-karierya1338

Multon, K. D., Brown, S. D., Lent, R. W. (1991). Relation of self efficacy beliefs to academic out comes. Journal of Counseling Psychology, 38, 30-38.

Nasta, K. A. (2007). Influence of career self-efficacy beliefes on career exploration behavior. State University of New York at New Paltz.

Oleś P. K. (2009). Wprowadzenie do psychologii osobowości. Warszawa: Scholar. 
Oleś, P. K., Drat-Ruszczak, K. (2008). Osobowość. In: J. Strelau, D. Doliński

(Eds.), Psychologia. Podręcznik akademicki (Vol. 1, pp. 651-764). Gdańsk: GWP. Parsons, F. (1909). Choosing a vocation. Boston: Houghton Mifflin.

Pervin, L. A. (2003). The science of personality. New York: Oxford University.

Pervin, L. A., John, O. P. (2001). Personality theory and research. NY: Wiley and Sons.

Piaget, J. Inhelder, B. (1969). The Psychology of the Child. NY: Basic Books.

Piotrowski, K. (2010). Wkraczanie w dorosłość. Warszawa: SCHOLAR.

Poulin, M. J. Heckhausen, J. (2007). Stressful events compromise striving during a major life transition. Motivation and Emotion, 31, 300-311.

Roe, A. (1956). The psychology of occupations. New York: John Wiley.

Rosch, E., (1978). Principles of Categorization. In Rosch, E. Lloyd, B.B. (Eds), Cognition and Categorization (pp. 27-48). Lawrence Erlbaum Associates.

Rosch, E., (1983). Prototype classification and logical classification: The two systems. In Scholnick, E., New Trends in Cognitive Representation: Challenges to Piaget's Theory (pp. 77-86). NJ: Lawrence Erlbaum Associates.

Rożnowski, B. (2009). Przechodzenie młodzieży z systemu edukacji na rynek pracy: Analiza kluczowych pojęć dotyczacych rynku pracy u młodzieży. Lublin: Wydawnictwo KUL.

Rożnowski, B. (2007). Sytuacja psychologiczna młodzieży wchodzącej na rynek pracy w perspektywie doradztwa zawodowego. In: A. Biela (Eds.), Nauka pracy, doradztwo zawodowe i przedsiębiorczość młodzieży (pp. 90-105). Warszawa: Kancelaria Senatu.

Rożnowski, B., Markowski, K., Łobocki, J., Konefał, K. (2006). Lokalne rynki pracy województwa lubelskiego w świetle opinii pracodawców, pracowników i młodzieży. Lublin: Instytut Rynku Pracy.

Rożnowski, B., Markowski, K., Łobocki, J., Konefał, K. (2007). Postawy i zachowania uczestników lokalnego rynku pracy. Lublin: Instytut Rynku Pracy.

Savickas, M. L. (1994). Donald Edwin Super: the career of a planful explorer. The Career Development Quarterly, 43, 4, 16-27.

Scholz, U., Dona, B. G., Sud, S., Schwarzer, R. (2002). Is General Self-Efficacy a Universal Construct? European Journal of Psychological Assessment. 18, 3 , 242-251

Schwarzer, R. (1992). Self-efficacy: Thought control of action. Washington, DC: Hemisphere.

Schwarzer, R, Jerusalem, M. (1992) Self Efficacy as a Resource Factor in Stress Appraisal Processes. In: Schwarzer, (Eds.). Self-Efficacy. Thought control of action. Washington, D.C. Hemisphere. 
Schwarzer, R., Jerusalem, M. (1995). Generalized self-efficacy scale. In J. Weinman, S. Wright, M. Johnston (Eds.), Measures in health psychology: A user's portfolio (pp. 35-38). Windsor: NFER-Nelson.

Skaalvik, E. M., Skaalvik, S. (2004). Self-concept and self-efficacy: A test of the Internal/External Frame of Reference model and predictions of subsequent motivation and achievement. Psychological Report, 95, 1187-1202

Spielberger, C. D. (1966) Theory and research on anxiety. Im C. D. Spielberger (eds.), Anxiety and Behavior. New York: Academic Press

Strajkovic, A. D., Luthans, F. (1998). Self-eficacy and work-related performance: a metaanalisis. Psychological Bulletin, 124, 240-261

Super, D. E. (1990). A life-span, life-space approach to career development. In D. Brown, L. Brooks (Eds), Career choice and development (pp. 197-261). San Francisco: Jossey- Bass.

Super, D. E., Larry, O.W. (1992). Developmental Career Assessment and Counseling: The C-DAC Model. Journal of Counseling Development, 9/10, 71.74-81, Super, D.E. (1972). Psychologia zainteresowa . Warszawa: PWN.

Super, D.E. (1994). A life span, life-space perspective on convergence. In: M.L. Savickas, W.W. Lent (Eds.), Convergence in career development theories. (63-74). Palo Alto, California: CPP BOOKS.

Super, D.E., Savickas, M.L., Super, C.M. (1996). A Life-Span, Life-Space Approach to Career Development. In: D. Brown, L. Brooks, (Eds.), Career choice and deve-lopment, 121-178. San Francisco, Jossey-Bass.

Tamir M., John O.P., Srivastava S., Gross J.J. (2007). Implicit Theories of Emotion: Affective and Social Outcomes Across a Major Life Transitio. Journal of Personality and Social Psychology, 92, 4, 731-744.

Tchibozo G. (2002). Meta-functional Criteria and School-to-work Transition. Journal of Education and Work, 15, 3, 337-350.

White, H. R., Jackson, K. (2004/2005). Social and Psychological Influences on Emerging Adult Drinking Behavior. Alcohol Research and Health, 28, 182-190.

Zimmerman, B. J., Bonner, S., Kovach, R. (1996). Developing self-regulated learners: Beyond achievement to self-efficacy. Washington, DC: American Psychological Association. 